\title{
Does Leadership Background Matter in Performance of Local Government?
}

\author{
Abdul Rahman, Abdul Rasyid Sahar, Fahdiansyah Putra \& Rahmadi Diliawan \\ University of Indonesia, Republic of Indonesia \\ abdul.rahman2418@gmail.com
}

\begin{abstract}
The local government's success of the development acceleration and the governance is currently dependent on the four dimensions of its supporters. One of them is the aspect of the leader who has the authority and function in designing the trajectory framework of the regional development policy in his area. In the process of democratic consolidation which is increasingly inclusive, the emergence of new leaders and elites in the constellation of local elections progressively colors political contestation in the regions. The performance achievements of the leaders and the regional development through the ranking formulated by the Ministry of Home Affairs in four assessment mechanisms show interesting results and data to study more deeply. This study tries to describe the backgrounds of local leaders that have implications for the central and local government's performance. This background has the significance and determination of the local leader ranking index. The results of this study indicate that the leaders who have Professional and Academic backgrounds have higher and better ranks compared to the ones who are politicians that may have political relations to cartels and clientelism within the locus of local government.
\end{abstract}

\section{Keywords: Governance, Leadership Background, Bureucracy, Clientelism}

\section{Introduction}

Local leader is a political as well as public position. It is categorized as a political position because the leader is chosen through political contestation and electoral process. On the other hand, the public position emerges as the elected leader has responsibility to the public. Both labels make the tasks of a local leader complex and difficult. In relation to it, the constitutional mandate set forth in Law No. 23 of 2014 on Regional Government, Article 65 states that a local leader has duties such as: leading the execution of government affairs which become regional authority under the provisions of laws and policies established with Regional House of Representatives (DPRD), maintaining the society's peace and order, drafting and proposing the draft of Regional Regulation (Perda) on Regional Long-Term Development Plan (RPJPD) and the ones on Regional Medium-Term Development Plan (RPJMD) to DPRD.

The execution of local autonomy in the context of democracy gives space to all elements of society in running for a local leader. In the democracy consolidation phase, Indonesia has given freedom in forming unities, conducting direct and open elections, and overcoming political destabilization as well as reconciling dominant political actors into democratic "rules of the game" (Tornquist, 2016). As a logical consequence, the elected local leader spread throughout Indonesia has backgrounds from various professions such as bureaucrats, politicians, businessmen, activists, academicians and even celebrities. On one hand, the phenomenon represents the uniqueness of democracy and enriches the styles of leaders in all regions in Indonesia. But, on the other hand, a question also raises on how their backgrounds (especially at the city level) becomes essential to boost the quality performance 
of local government?

One of the entities which having tasks and responsibilities (candidates) of regional head is a political party. Considering that a political party is one of the pillars of the democratic system. Furthermore, political scientists often describing 4 (four) functions of political parties. The four functions of the political party according to Miriam Budiardjo are: (i) political communication, (ii) political socialization, (iii) political recruitment, and (iv) conflict regulators. Meanwhile, interpretation of Yves Meny \& Andrew Knapp 1968) defining the function of the political party includes the functions of (i) mobilization and integration; (ii) influencing voter behaviour; (iii) political recruitment; and (iv) elaborating policy options (Budiarjo, 1992).

On the other hand, Indonesia has various problems in the political system such as: a) Inefficiency of Political Parties. The number of political parties in Indonesia, which is 73 political parties, is very contrasting with the number of political parties in several countries such as: United States of America (2), New Zealand (5), Pakistan (6), Cambodia (7) and Germany (10). Excess quantity of political parties is practically causing much more interests; b) Ineffectiveness of Political Party. From 73 political parties ${ }^{1}$, only 14 political parties that pass the selection and become participants of the General Election in $2019^{2}$. This indicate that even quantity of political parties is very large, but not yet effectively categorized; c) Diversification of professional background (candidate) Head of Region such as: bureaucrats, politicians, businessmen, activists, academics and even celebrities. In the trajectory democracy it has indeed been done legitimacy, but gradually still required more testing whether the diversification can be take a responsibility, or even cause problems. Therefore, this research becomes appealing with reviewing more deeply "Does Leadership Background Matter in Performance of Local Government?"

\section{Research method}

This research using descriptive research analysis. Meanwhile the 12 (twelve) city-level regions in all regions in Indonesia such as: Bengkulu, Bitung, Depok, Kediri, Kupang, Malang, Makassar, Pare-Pare, Payakumbuh, Subussalam, Sorong, and Tual are selected by randomly based on the representation of time zone distribution in Indonesia, namely: West Indonesia Time (WIB), Central Indonesia Time (WITA) and Eastern Indonesia Time (WIT). Then the twelve regions reviewed in the background of their respective Local Leader profession before they are officially elected as public officials in their administrative areas, then traced by Ministry of Home Affairs Indonesia (KEMENDAGRI) for the 2 (two) periodes of public officials. So that the results of the study are expected to represent the profile of the Local Leader in accordance with the Indonesian democratic style and the needs of the local regions (especially cities) that exist throughout the territory of Indonesia.

Meanwhile, the data collection conducted in this research using literature research techniques. Literature research limits activities to literature materials without the require field research (Zed, 2008). The primary data is "Performance Evaluation of Local Government Implementation (EKPPD)" obtained from the Ministry of Home Affairs of the Republic of

\footnotetext{
${ }^{1} \mathrm{http} / / /$ www.tribunnews.com/nasional/2017/10/17/73-partai-terdaftar-cuma-27-parpol-yang-daftar-jadi-peserta-pemilu-2019

2 https://nasional.kompas.com/read/2018/02/17/13333761/ini-14-partai-politik-peserta-pemilu-2019
} 
Indonesia, while the secondary data comes from: books, journals and websites on the internet. On the other hand, the data analysis which used in this research is interactive model analysis from Miles and Huberman (2005), which divides into several parts such as: data collection, data reduction, data display, and conclusion or verification.

\section{Literature review}

Within the framework of conceptual and factual, the leader has significance in the process of determining the direction of the organization. This premise is based on the reality that the leader is the highest authority in decision and policy makers. If traced factually, leaders have a very strong dominance in accommodating instruments of power that to achieve a variety of objectives and interests. In public policy concepts, argumentation Dye and Zeigler showed that public policies generated by government entities is the result of the preference of the leaders who were in power (Dye, 1975). Furthermore, Wright Mills (1956) emphasizes that in the typology of public policies that have implications for the wider community, directions and decisions derived from perspectives and preferences of elite individuals who have authority. This premise refers to Mills (1956), which states that;

"Reviews those political, economic, and military circles, which as an intricate set of overlapping cliques share decisions ... in so far as national events are Decided, the power elite are Reviews those who decide them."

"The power elite is composed of men whose positions enable them to transcend the ordinary environments of ordinary men and women, they are in positions to make-such decisions having major consequnces is less important than the fact that they do occupy such positionspivitol.

As an illustration of the vital role and significance of the leader, can be seen from the illustration below;

Picture. 1 Elite Models in Policy

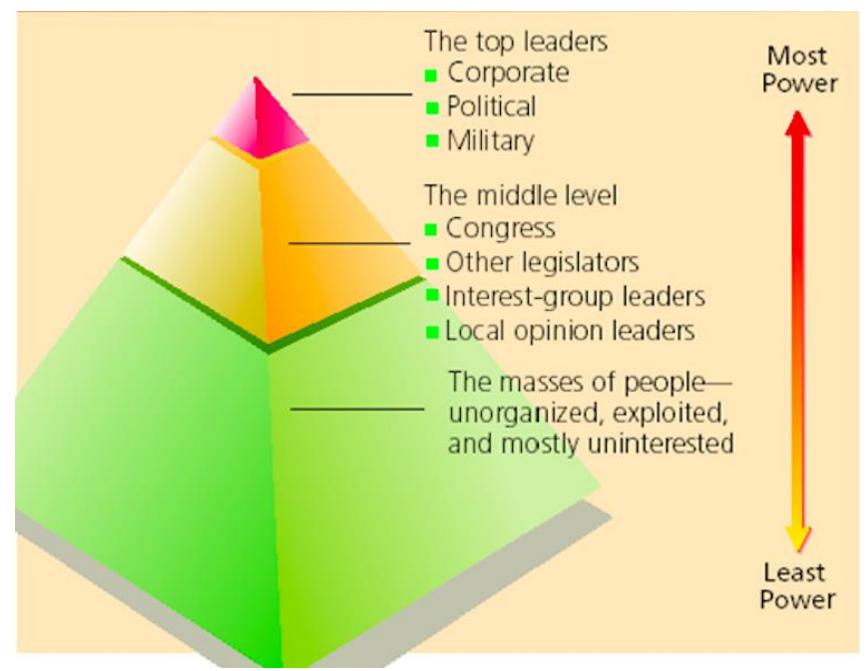

Source: C. Wright Mills, 1956, The Power Elite New York: Oxford University Press. 
In addition, the various concepts and theories in public policy leaders showed an important role in taking the step and decide a policy in organizational entities, both of which are within the scope of the democratic and authoritarian systems. Riant Nugroho (2017) also elaborates on the significance of leaders in every stage of the policy as shown below;

Figure 2. The leader's role in the policy process

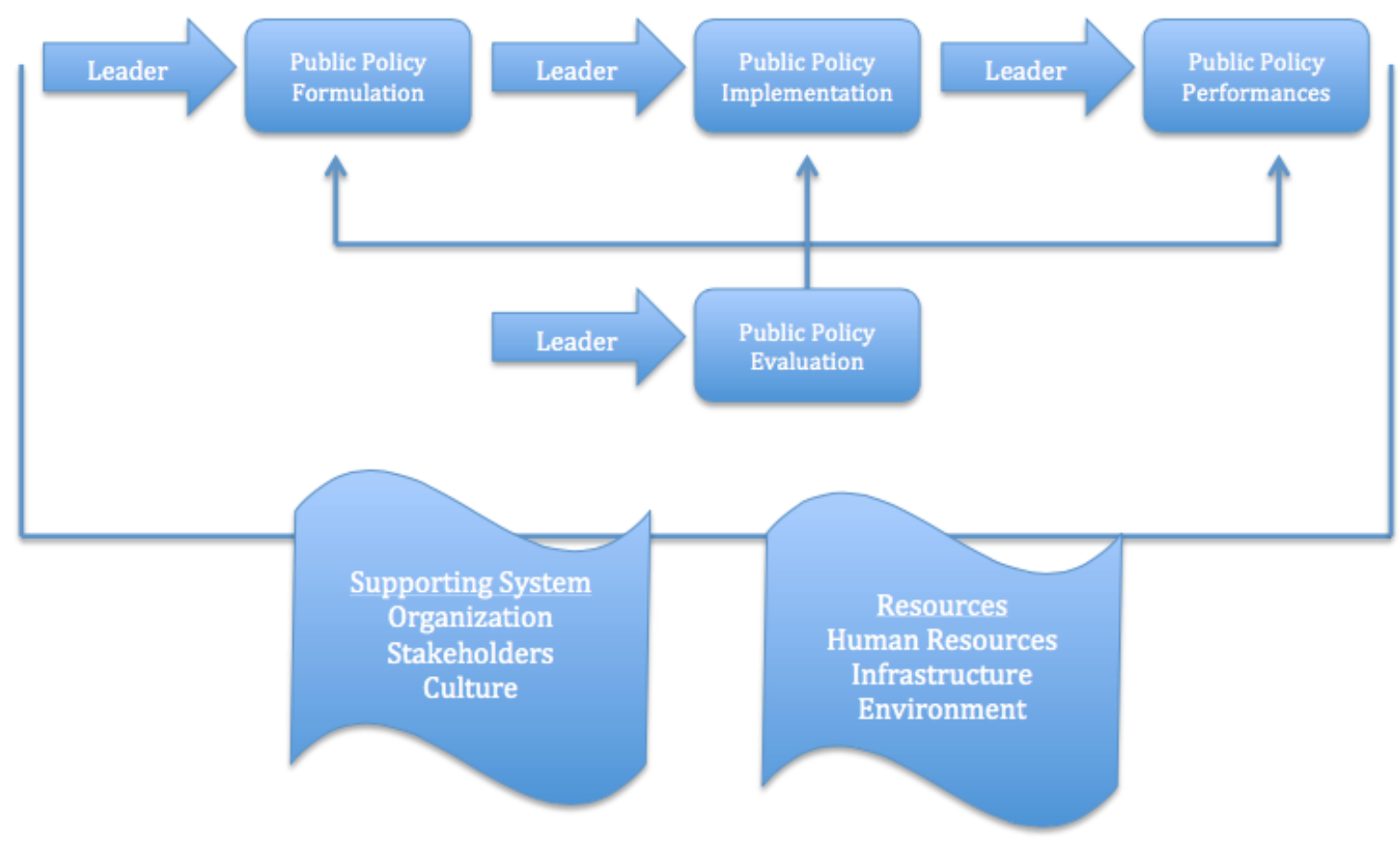

Source: Riant Nugroho, 2017. Public Policy, Jakart: Elex Media Komputindo

Referring to the portrait above, it can be interpreted that in all stages of public policy, the leader is present as a figure who ensure the system is running in accordance with the capacity and capability which are owned. Leaders have significant authority device in every stage of the process and public policy. Therefore, the operational definition of a leader in this research is referring to the head area served as a public and political official in the administration of each. In addition, this study emphasizes how background affect the performance of government leaders.

In the context of Indonesia, big bangdecentralization impact inclusive to local authorities in this case against the local government authority and responsibility of the political and administrative implicitly. This then encourages the perpetrators or local actors directly involved in electoral contestation to be a public official. Research conducted by Olle Tornquist (2016), showed that after the fall of the New Order regime, the pattern of power relations between the dominant actor-alternate with groups and colleagues as well as networking oligarchs who are affiliated with the strength of the new order be reduced by the consolidation process of democratization after the 1998 reform (Read Olle Tornquist report on Reclaiming the State 2016). The dominant actors and the alternative here is to refer to individuals who win electoral contestation and holding power without connection and affiliation with the New Order 
government corporatism. Furthermore, the study would then operationalize the concepts above to dissect how the individual's background and the dominant or alternative actors able to oversee every stage of the policy process and the decision taken in order to improve the quality of life and public services at each locus administration.

\section{Result and discussion}

The Indonesian Constitution essentially provides a vast space for all citizens to participate as candidates in the elections. As a reflection of democracy, of course, it is a positive linear. But as an output of qualified political contestation, absolutely, it requires testing process, so that the regions (especially the city level) can be said to be relatively successful in choosing the local leaders if the elected officials are able to bring welfare and encourage innovation and competitive areas both nationally and internationally.

The government represented by the Ministry of Home Affairs has tried to accommodate the measurement of regional performance through four performance evaluation mechanisms, namely EPPD (Evaluation of Local Government Implementation), EKPPD (Evaluation of Local Government Implementation Performance), EKPOD (Evaluation of Regional Autonomy Implementation Capacity), $E D O B$ (Evaluation of New Autonomous Region). The results of these four measurements are embodied in a Decree of the Minister of Home Affairs on National Rating Determination and Performance Status of the Implementation of Local Governance which is held annually. Therefore, the local leader can carry out evaluative and introspective steps as a response to the rank.

Referring to the Decree of the Minister of Home Affairs Number 120 - 10421 Year 2016 on Rating Determination and Performance Status of Local Government Organization Year 2015, the researchers conducted a case study investigation on 12 city-level regions from a total of 91 cities throughout Indonesia. The empirical data show the tendency that the local leaders having background as academicians, entrepreneurs, and professionals are able to bring the city they lead to get a satisfactory ranking by occupying the position of the top 20 best cities in 2015.

Meanwhile, local leaders with backgrounds as politicians and bureaucrats tend to rank poorly in 2015 . The details of the 12 cities are as follows:

Regional Rating According to the Ministry of Home Affairs Viewed from the Background of Local Leader in 2015

\begin{tabular}{|r|l|l|l|l|c|}
\hline No. & \multicolumn{1}{|c|}{ Region } & $\begin{array}{c}\text { Local Leader's } \\
\text { Name }\end{array}$ & \multicolumn{1}{|c|}{ Background } & Period & $\begin{array}{c}\text { Ranking in } \\
\mathbf{2 0 1 5}\end{array}$ \\
\hline 1 & Subulussalam & $\begin{array}{l}\text { Merah Sakti } \\
\text { Kombih }\end{array}$ & Politician & $2014-2019$ & 90 \\
\hline 2 & Payakumbuh & Riza Falepi & Entrepreneur & $2012-2017$ & 20 \\
\hline 3 & Bengkulu & Helmi Hasan & Politician & $2013-2018$ & 83 \\
\hline 4 & Depok & $\begin{array}{l}\text { Nur Mahmudi } \\
\text { Ismail }\end{array}$ & Professional & $2011-2016$ & 7 \\
\hline 5 & Kediri & Abdullah Abu & Professional & $2014-2019$ & 15 \\
\hline
\end{tabular}




\begin{tabular}{|r|l|l|l|l|c|}
\hline No. & \multicolumn{1}{|c|}{ Region } & $\begin{array}{c}\text { Local Leader's } \\
\text { Name }\end{array}$ & Background & Period & $\begin{array}{c}\text { Ranking in } \\
\mathbf{2 0 1 5}\end{array}$ \\
\hline & & Bakar & & & \\
\hline 6 & Malang & $\begin{array}{l}\text { Mochamad } \\
\text { Anton }\end{array}$ & Entrepreneur & $2013-2018$ & 18 \\
\hline 7 & Kupang & Jonas Salean & Bureaucrat & $2012-2017$ & 66 \\
\hline 8 & Parepare & Taufan Pawe & Academician & $2013-2018$ & 14 \\
\hline 9 & Makassar & Danny Pomanto & Academician & $2014-2019$ & 1 \\
\hline 10 & Bitung & Hanry Sondakh & Politician & $2011-2015$ & 91 \\
\hline 11 & Tual & M Tamher & Politician & $2013-2016$ & 88 \\
\hline 12 & Sorong & Lambert Jitmau & Bureaucrat & $2012-2017$ & 87 \\
\hline
\end{tabular}

Source: Ministry of Home Affairs 2016 (Data Processed by Researcher)

The result of the assessment on regional performance and public officials above shows that the local leaders with backgrounds as academicians, entrepreneurs, and professionals tend to be able to bring the city they lead to get a good ranking. This statement refers to the local leaders' profession background as academicians such as Danny Pomanto (Makassar) and Taufan Pawe (Pare-Pare) who are successful in bringing their cities to 1st and 14th ranks. Next, the entrepreneur background owned by Riza Falepi (Payakumbuh) and Mochamad Anton takes their cities to 20th and 18th places. In accordance with the professional background, Nur Mahmudi Ismail (Depok) and Abdullah Abu Bakar (Kediri) succeed in bringing the cities to the rank of 7 and 15. By looking at these tendencies, it can be concluded that the background of a local leader is potential in influencing the performance of bureaucracy and policy in the government's administration locus.

Conversely, the local leaders having politician and bureaucrat backgrounds tend to rank relatively inferior for their led cities. From the background of politicians for example, Helmi Hasan (Bengkulu), Merah Sakti Kombih (Subulussalam), M Tamher (Tual) and Hanry Sondakh (Bitung) are ranked 83, 90, 88 and 91. Then, from the background of bureaucrats, Jonas Salean (Kupang) and Lambert Jitmau (Sorong) are also ranked poorly: 66 and 87.

In addition, it is interesting to note that similar trend also occurs in the previous reigns in the same cities. The following are the data collected by Decree of the Minister of Home Affairs Number 120 - 2818 Year 2013 on the National Determination of Rating and Performance Status of Local Government Administration in 2011: 


\section{Regional Rating According to the Ministry of Home Affairs Viewed from the Background of Local Leader in 2011}

\begin{tabular}{|c|c|c|c|c|c|}
\hline No. & Region & $\begin{array}{c}\text { Local Leader's } \\
\text { Name }\end{array}$ & Background & Period & $\begin{array}{c}\text { Ranking in } \\
2011\end{array}$ \\
\hline 1 & Subulussalam & $\begin{array}{l}\text { Merah Sakti } \\
\text { Kombih }\end{array}$ & Politician & 2009-2014 & 89 \\
\hline 2 & Payakumbuh & Josrizal Zain & Politician & $2007-2012$ & 43 \\
\hline 3 & Bengkulu & Ahmad Kanedi & Politican & $2007-2014$ & 78 \\
\hline 4 & Depok & $\begin{array}{l}\text { Nur Mahmudi } \\
\text { Ismail }\end{array}$ & Professional & 2006-2011 & 4 \\
\hline 5 & Kediri & Samsul Ashar & Professional & 2009-2014 & 19 \\
\hline 6 & Malang & Peni Suparto & Academician & $2003-2013$ & 14 \\
\hline 7 & Kupang & Daniel Adoe & Bureaucrat & $2007-2012$ & 76 \\
\hline 8 & Parepare & Sjamsu Alam & Politician & $2010-2013$ & 34 \\
\hline 9 & Makassar & $\begin{array}{l}\text { Ilham Arief } \\
\text { Sirajuddin }\end{array}$ & Politician & 2009-2014 & 28 \\
\hline 10 & Bitung & Hanry Sondakh & Politician & $2006-2011$ & 41 \\
\hline 11 & Tual & M Tamher & Politician & $2008-2013$ & 88 \\
\hline 12 & Sorong & $\begin{array}{l}\text { Jonathan Annes } \\
\text { Jumame }\end{array}$ & Bureaucrat & 2007-2012 & 73 \\
\hline
\end{tabular}

Source: Ministry of Home Affairs 2013 (Data Processed by Researcher)

The data indicate that the local leaders at the city level who have professional and academician backgrounds are able to bring the cities they lead achievement. The professionals such as Nur Mahmudi Ismail (Depok) and Samsul Ashar (Kediri) succeed in bringing the region to 4th and 19th ranks. It is linear with the achievement of the next period led by the incumbent, Nur Mahmudi Ismail (Depok), and Abdullah Abu Bakar (Kediri): 7 and 15. The academician, Peni soeparto (Malang), also gets good rank: 14, which is four-level better in rating compared to his successor Mochamad Anton (18) coming from the background of an entrepreneur.

However, the bureaucrat backgrounds have a tendency trend to be poorly ranked which is relatively similar to the leadership period thereafter. Daniel Adoe (Kupang) and Jonathan Annes Jumame (Sorong), for instance, only rank 76 and 73. These ranks are not much different from the local leaders thereafter, having bureaucrat backgrounds, namely Jonas Salean (Kupang) and Lambert Jitmau (Sorong) who only get 66th and 87th positions.

Politician backgrounds also tend to rank poorly. As an example, the incumbents like Merah Sakti Kombih (Subulussalam), Hanry Sondakh (Bitung) and M. Tamher (Tual) respectively get ranks of 89,41, and 88, while Ahmad Kanedi (Bengkulu) is ranked 78. But, it is interesting to see the position of Josrizal Zain (Payakumbuh) who is on 43rd rank, whereas in the era after it (listed in Table 1), Riza Falepi who is an entrepreneur successfully boost Payakumbuh's rank to 20th position. Similarly, Sjamsu Alam (Parepare) and Ilham Arief 
Sirajuddin (Makassar) who are politicians should be grateful to only get ranks of 34 and 28, since in the next reign, Taufan Pawe (Parepare) and Danny Pomanto who both have background of academicians are successful significantly in flying the region ranks on 14 and 1.

Furthermore, the regional ranking data released by the Ministry of Home Affairs as shown in Table 1 and Table 2 also concretely show an interesting reality: the local leaders having work backgrounds as academicians, entrepreneurs and professionals tend to rank well for 2 (two) reigns which indicate a positive trend. On the contrary, the local leaders having backgrounds as politicians and bureaucrats show a negative trend as during 2 (two) periods of leadership (either as an incumbent or not), they tend to have bad ranks.

\section{Elite Determination and Governance}

Understanding the above trend, several empirical studies show that all major policies in politics and governance are determined by a small group of individual elites. Moreover, David Beetham marks that the actor is the most crucial aspect of his involvement in democratic political processes. The historical track of the actor's existence has been captured in the power accumulation which asserts that all political institutions as well as societies are dominated by individuals who manipulate the instruments of power to strengthen their desires. It means that actors can be interpreted as the elites who have access to political supremacy and governance. Up to this point, the actor position is a key factor in explaining how public policy development moves more inclusively.

In addition, elite dominance is very significant in controlling all aspects of politics and governance. This phenomenon can be traced in a developing country that has direct contact with an authoritarian system. Robinson and Hadiz (2004) describe a system of government controlled by political elites who have great financial resources in the Post-New Order era. Furthermore, Dye and ZieMietzner (2012) point out the same premise that in Post-Soeharto's regime, rich elites play a key role in slowing the pace of democratization in Indonesia.

In recent years, the tendency of new populist leaders who have won political contestation in direct elections leaves a note in the pace of Indonesian democratization. These actors' success is due to their agility in managing public issues as political campaign materials. Additionally, the issue of public welfare becomes a concern among Indonesians. Many people also get more understanding on the central role of the state in the provision of public services. This finally gives impact for the elected public officials to produce quality and reliable public policies.

The administration led by political officials from the professional and academician backgrounds demonstrates the spirit and practice of good governance. This is because they have no personal connections to the oligarchies or party elites that can cause conflicts of interest within the bureaucracy. Consequently, after being selected as political and public officials, they could work hard and dedicate themselves to serve and accommodate the society's aspirations in the locus of governance they lead.

In contrast to public officials coming from party cadres, the governance they lead does not comprehensively represent the society's hopes. Moreover, the governance tends to run badly. This is influenced by the high cost of politics in accumulating and mobilizing support, as well as the obligation to pay political and operational dowry during the candidature process 
to the election. Therefore, the policies' qualities and implementations affect the performances of the government and the acceleration of regional development.

From the study conducted by PolGov UGM, some individuals who have been identified as new elites and populist leader are indicated to become elected public officials such as Ridwan Kamil as Mayor of Bandung, Reza Pahlevi as Payakumbuh Regent, Nurmahmudi Ismail as Mayor of Depok, Nurdin Abdullah as Bantaeng Regent, Danny Pumanto as Mayor of Makassar, and Taufan Pawe as Pare-Pare Mayor. The difference in the work background before becoming public officials does not change the orientation of their views in carrying out the mandate and working hard for the sake of all their constituents' prosperity. Through their work, they succeed in proving to the public that they are leaders who have worked hard for the welfare of the people through policy reforms. They are also successful in constructively make the people understand that they have no patronage with oligarchs or party elites who could affect their public policy (Amalinda Savirani, 2016).

\section{Conclusion}

The selected political officials who are either in the provincial or in the local government reflect transparent governance, accountability and responsive public services. This refers to the ranking earned by each local leader. This achievement is supported by the condition that they have no personal connections to the oligarchy and parties that may create a conflict of interest. Some empirical studies show that the high cost of political contestation demands political leaders or officials to provide much money. It results in a tendency that policies they publish after being public officials do not represent the interests of the people in general. In contrast, the policies might be based on the interests of elites and oligarchs in the Post-New Order. This is a reflection of the relation pattern between local leader background and the performance of local government.

\section{Recommendation}

This research resulted in the following recommendations:

1) Referring to the above report, individuals who become dominant actors and alternative backgrounds Academics, Professionals and Entrepreneurs should be going politics to reduce the pattern of power relations between the oligarchs and the power of the new order so that in the process and stages of the policy will be more deliberative and emphasis on consensus.

2) In the context of the election of public officials in Indonesia, electoral contestation become an annual event that is recognized by the constitution. In addition, the fundamental problems that escaped resolved by political parties in Indonesia are kartelisme practices that hamper the merit principle in the process of regeneration party system so that public officials whose background politicians tend to result in lower government performance and unresponsive. Therefore, in creating leaders and public official quality and integrity, it is necessary to reform political party perkaderan more comprehensive. What this means is, the cadres of political parties should have the competence and militancy and strategic position in the placement process structural position of the party is based on the principle of meritocracy. 


\section{References}

Bastian, Indra. (2014). Sistem Pengendalian Manajemen Sektor Publik. Jakarta: Salemba Empat.

Beetham, D. (1999). Democracy and Human Rights. Oxford: Polity Press.

Savirani, Amalinda. (2016). Reclaiming the State: Mengatasi Problem Demokrasi di Indonesia Pasca-Soeharto. Yogyakarta: PolGov \& PCD Press.

Budiardjo, Miriam. (1992). Dasar-Dasar Ilmu Politik. Jakarta: Gramedia Pustaka Utama.

Bogdan, Robert dan Steven Taylor. (1992). Pengantar Metode Kualitatif. Surabaya: Usaha Nasional.

Baswedan, Anis. (2007). Politik Lokal Di Indonesia. Jakarta: Yayasan Obor Indonesia.

C. Wright Mills. (1956). The Power Elite. New York: Oxford University Press.

Danim, Sudarwan. (2002). Menjadi Peneliti Kualitatif. Bandung: Pustaka Setia.

Diamond, Larry. (1999). Developing Democracy toward Consolidation. Yogyakarta: IRE Press.

Nurcholis, Hanif. (2007). Teori dan Praktik Pemerintahan dan Otonomi Daerah. Jakarta: Grasindo.

Kencana, Syafiie Inu. (2005). Pengantar Ilmu Pemerintahan. Bandung: PT Refika Aditama.

Miles, Matthew B. and A. Michael Huberman. (2005). Qualitative Data Analysis (terjemahan). Jakarta: UI Press.

Nugroho, Riant. (2017). Public Policy, Jakarta: Elex Media Komputindo.

Tornquist, O. (2013). Assesing Dynamics Democratisation. Transformative Politics, new Institutions, and the case of Indonesia. New York: Palgrave.

Thomas R. Dye dan Harmon Zeigler, (1970). The Irony of Democracy, Belmont, Calif: Wadworth.

Varma. Sp. (2007). Teori Politik Moderen, Jakarta: Gramedia.

Zed, Mestika. (2008). Metode Penelitian Kepustakaan. Jakarta: Yayasan Obor Indonesia.

\section{Constitution}

Undang-undang Republik Indonesia Nomor 23 tahun 2014 tentang Pemerintahan Daerah PP Nomor 8 Tahun 2006 tentang Pelaporan Keuangan dan Kinerja Instansi Pemerintah.

Keputusan Menteri Dalam Negeri Nomor 120 - 2818 Tahun 2013 tentang Penetapan Peringkat dan Status Kinerja Penyelenggaraan Pemerintahan Daerah Secara Nasional Tahun 2011.

Keputusan Menteri Dalam Negeri Nomor 120 - 10421 Tahun 2016 tentang Penetapan Peringkat dan Status Kinerja Penyelenggaraan Pemerintahan Daerah Secara Nasional Tahun 2015.

\section{Internet}

https://daerah.sindonews.com/read/837417/23/tri-rismaharini-bukan-kader-politis-pdip$\underline{1392834867}$

https://megapolitan.kompas.com/read/2016/09/23/20014801/anies.baswedan.bukan.kader.ger indra.dan.pks.ini.kata.prabowo 